\title{
Twitter Diplomacy@Kemlu_RI: A Case Study of Bali Democracy Forum 2019
}

\section{Ludiro Madu}

Universitas Pembangunan Nasional "Veteran" Yogyakarta, Indonesia ludiro.madu@upnyk.ac.id

Submitted: 23 April 2021; Revised: 5 July 2021; Accepted: 20 July 2021

\section{Check for updates}

\begin{abstract}
Abstrak
Peningkatan penggunaan media sosial, khususnya Twitter, telah mendorong Kementerian Luar Negeri Indonesia (Kemlu RI) membuat akun Twitter resmi@Kemlu_RI untuk menyebarkan informasi. Artikel ini bertujuan untuk mengevaluasi penggunaan Twitter dalam diplomasi Indonesia melalui akun resmi Kemlu RI (MOFA). Penelitian ini menggunakan pendekatan kualitatif. Data diperoleh melalui observasi tren percakapan di Twitter dengan memantau akun @Kemlu_RI dengan fokus pada penggunaan hashtag \#BDF2019. 'Drone Emprit Academic' (DEA) digunakan sebagai alat untuk mengumpulkan data. Pengumpulan data diperoleh dari percakapan Twitter selama lima hari. Analisis DEA menghasilkan 1.088 percakapan. Pengumpulan data melalui DEA di @Kemlu_RI ternyata menghasilkan temuan lain. Hasil penelitian ini menunjukkan bahwa penggunaan DEA lebih memberikan manfaat bagi diplomasi digital Indonesia, seperti top hashtag, top influencer, analisis jejaring sosial, dan pengguna banyak terlibat daripada sekedar penyebaran informasi BDF secara umum. Data yang diperoleh melalui DEA ini bermanfaat untuk melakukan evaluasi atas diplomasi Twitter melalui hastag \#BDF2019 oleh @Kemlu_RI. Diplomasi Kemlu Indonesia melalui Twitter dapat meningkatkan arti penting penggunaan Twitter dalam agenda diplomasi di masa depan.
\end{abstract}

Kata Kunci: Drone Emprit Academic, @Kemlu_Rl, Indonesian MOFA, Bali Democracy Forum, Indonesian digital diplomacy, \#BDF2019.

\begin{abstract}
Following the increasing use of social media, particularly Twitter, the Indonesian Ministry of Foreign Affairs (MOFA) made an official Twitter account @Kemlu_Rl for disseminating information. The paper aims to analyze the trend of tweeting at the official Twitter account of the Indonesian MOFA, @Kemlu_RI. This research used a qualitative approach. Data were obtained through observation of the conversation trend on Twitter by monitoring the @Kemlu_Rl account. This research focussed on the use of hashtag \#BDF2019. Using 'Drone Emprit Academic' (DEA), this research collected data on five days of Twitter conversations. The DEA analysis resulted in 1,088 conversations. Rather than only disseminating information, the use of DEA for analyzing \#BDF2019 at @Kemlu_RI turned out to produce more findings. The results of this study revealed that the DEA usage gave more benefits to Indonesian digital diplomacy, such as top hashtags, top influencers, social network analyses, and most engaged users, rather than just general dissemination of information of the BDF 2019. Therefore, the use of the DEA is highly significant for resulting in more accurate data for the Indonesian MOFA to manage a better strategy for using Twitter in its future diplomatic agenda.
\end{abstract}

Keywords: Drone Emprit Academic, @Kemlu_RI, Indonesian MOFA, Bali Democracy Forum, Indonesian digital.

\section{INTRODUCTION}

Social media has become an inseparable part of recent diplomatic relations. It significantly influences and transforms practices of diplomacy (Duncombe, 2017). As one of the most widely used social media, Twitter, has become more popular in the diplomatic environment of many countries (Chhabra, 2020). Twitter is initially a social media to deliver various information between individuals in a national borderless society, but it has increased and plays an essential role in international relations (Collins, DeWitt, \& LeFebvre, 2019). Twitter diplomacy is run by various foreign ministries (Strauß, Kruikemeier, van der Meulen, \& van Noort, 2015) and embassies around the world (Manor \& Segev, 2020). Through digital diplomacy on Twitter, diplomats use 
digital communication tools (social media) to communicate with each other and the general public (Mattoš, 2015). Diplomats at the Ministry of Foreign Affairs specifically use Twitter as a tool to interact directly with both the domestic and foreign public (Sobel, Riffe, $\&$ Hester, 2016). This development has become a new practice in the 21st century (Chhabra, 2020).

Following the increasing use of social media, particularly Twitter, the Indonesian Ministry of Foreign Affairs (MOFA) made an official Twitter account @Kemlu_RI. The use of Twitter shows that the Indonesian MOFA understands the increasing importance of Twitter in Indonesian diplomacy. The case of the Bali Democracy Forum (BDF) 2019 depicts the ways the MOFA informed the BDF 2019 to the public through its special hashtag \#BDF2019. The primary purpose of using Twitter at BDF 2019 was to promote this annualdiplomatic agenda in @Kemlu_RI so that the public was aware and responded to it. Studying activism of the Indonesian MOFA in social media, specifically, Twitter is essential for its strategic position in the Indonesian Government to pursue its national interest. The problem is that the MOFA did not announce the extent of the success of Twitter's use in supporting the implementation of BDF 2019. However, this information is essential for MOFA and society. Further inquiries are closely related to the extent to which information dissemination of BDF 2019 reached the community and community participation rates in conversations on Twitter, particularly at the @Kemlu_RI account through \#BDF2019. Without this information, the MOFA could not assess or evaluate Indonesia's digital diplomacy policy, especially in the implementation of BDF 2019.

The policy of the Indonesian MOFA using Twitter to support the implementation of BDF 2019 should not only be intended to convey information so that people know the annual activity. However, the use of Twitter should also be able to provide more useful information for Indonesia's digital diplomacy policy. As a result, this paper employed 'Drone Emprit Academic' (DEA) to analyze trending topics at @Kemlu_RI to maximize the benefits of MOFA's digital diplomacy. Therefore, this is highly urgent to analyze the trend of conversation on Twitter, especially at MOFA's official account @Kemlu_RI, with its special hashtag \# BDF2019.

\section{LITERATURE REVIEW}

More and more countries are using social media platforms in international relations. As Manor and Segev (2015) mentioned, digital diplomacy refers more to the increasing use of social media platforms by most countries to conduct diplomacy as well as shape their image and international reputation actively. Countries take advantage of digital diplomacy at the level of foreign ministries and embassies around the world. Another definition of digital diplomacy emphasizes the digital activity (social media) of diplomats to communicate between them and with the international audiences (Lewis, 2014) via mobile devices (Potter, 2002) to achieve their country's diplomatic goals (Hanson, 2012).

In the context of digital diplomacy, the MOFA and embassies have turned into active actors on online social networks. The goal is to disseminate, collect, and analyze information (Manor, 2015). In addition, diplomat activism has fundamentally expanded communication between policymakers and citizens on social media. Various social media, such as Facebook, Twitter, Instagram, YouTube, and others, have become essential means for diplomatic missions. Diplomats can gain direct access to citizens, both inside and outside the country. With this rapid development, various countries should be able to regulate the dissemination of information (Rold, 2018).

Digital diplomacy allows countries to use platforms such as Twitter to serve their diplomatic interests. Diplomatic circles have also used Twitter; thus, this social media has evolved into a kind of network known as 'twiplomacy.' The term refers to the efforts of people in the modern world in establishing social relationships by "following" each other on Twitter (Verrekia, 2017). Through this social media platform, Twitter users can post various information, follow other people's tweets, and repost information they like (Umakanth \& Santhi, 2020). 
In the same way, diplomats use Twitter to pass on information about their country to international audiences. Communication among Twitter users occurs through mentions and answers to previous tweets. Twitter's social media popularity among diplomats is one of the focuses of this article (Sevin et al., 2018). Twitter users usually create and use certain hashtags as keywords. The hashtag describes specific tweets and helps Twitter users to search for specific information on Twitter (Small, 2011). Therefore, the use of hashtags has a significant meaning in managing various crucial diplomatic information on Twitter (Ittefaq, 2019).

Through a case study on BDF 2019, this article shows that Twitter has provided many ways to influence others. By direct interaction using \#hashtags, Twitter has directly connected communities with similar interests. Furthermore, Twitter users can repeat the message via "retweet" to another follower (Gruzd \&Wellman, 2014) or answer via "reply" to the message. Twitter also allows its users to know the level of community participation or "conversation". Public participation in certain information on Twitter can be known through mentions, retweets, and replies can be a measure of successful deployment (Booten, 2016). In this article, the three forms of information can be obtained through MOFA's official Twitter account, namely @Kemlu_RI through \#BDF2019. In addition, information about Twitter conversations at the account with a particular hashtag also shows internal support and commitment (Al-Muftah, Weerakkody, Rana, Sivarajah, \& Irani, 2018) within MOFA Indonesia, including Indonesian representative offices abroad.

There are two essential purposes for using Twitter hashtags: first, to understand the broader influence of the information being transmitted; the second goal is to determine the breadth of their tweets among Twitter users (Collins, DeWitt, \&LeFebvre, 2019). Both objectives demonstrate the commitment of the information maker through that particular hashtag, such as \#BDF2019 in the BDF 2019 case study. Through the hashtag, the number of mentions, retweets, and replies has significance as a form of institutional support. Moreover, the same applies to the official hashtag
\#IniDiplomasi from MOFA Indonesia's account and more than 130 Indonesian representative offices abroad. In the context of Twitter, top influencers have an essential role and influence to increase their follower count into conversations about a particular issue through specific hashtags (Dodd \& Collins, 2017), such as \#BDF2019.

As one of the key agendas in Indonesia's annual multilateral diplomacy, BDF 2019 aimed to promote the development of political freedom and openness (Brigg, Wilson, de Jalong, \& Sugiono, 2016) among various countries of the Asia Pacific region. Besides, BDF 2019 also encouraged the expansion of participatory and open democratization (Lie \& Siagian, 2018). What is interesting is that BDF 2019 affirmed MOFA Indonesia's commitment to digital diplomacy. Since its inception, BDF 2019 was formed as a forum for Asia-Pacific countries. Nevertheless, the forum has grown rapidly by attracting the participation of more countries in Europe and North America (Grzywacz, 2019). This significant increase in the number of participants has proven the increasing importance of Indonesia's role and influence in leading the BDF. Moreover, the increasing number of participants also demonstrated recognition from the international community of Indonesia's serious efforts to spread democratic values in the region (Duncombe, 2017)

\section{RESEARCH METHOD}

This research applied a qualitative approach. This article conducted Social Network Analysis using DEA as a gathering tool to evaluate the effectiveness of \#BDF2019 by @kemlu_RI on Twitter. Data were obtained through observation of the conversation trend on Twitter by monitoring the @Kemlu_RI account. Twitter developed into a social media that functions to obtain data about the news being a trending topic of people's conversations (Saravanan, Masthan, Kethri K, Harsha, \& Reddy, 2020). In collecting data, this research focussed on the use of hashtag \#BDF2019 at @Kemlu_RI. A hashtag is a useful tool for interacting, expressing opinions between individuals and a community, and pooling resources from Twitter (Xiong, 
Cho, \& Boatwright, 2019). These research data were limited to five days. The BDF 2019 was held from $5^{\text {th }}$ to $6^{\text {th }}$ December 2019. This study resulted in 1,088 active Twitter users from $3^{\text {rd }}$ to $7^{\text {th }}$ December 2019 (Figure 1). Data were processed using a system owned by the DEA (Laagu \& Setyo Arifin, 2020). The DEA uses a big data system to mine and analyzes conversations on Twitter (Suharso, 2019), specifically at the @Kemlu_RI account. Through PT. Media Kernels Indonesia, the DEA system was developed (Anam, M Kolopaking, \& A Kinseng, 2020) and installed in the data center of the Information System Board of Universitas Islam Indonesia, Yogyakarta (Fahmi, 2017). Based on the data obtained by the DEA, the author descriptively analyzed Twitter conversation data. The data, as indicated in all figures (1-4) and table (1), in this paper were originated from the DEA at UII Yogyakarta.

\section{RESULT AND ANALYSIS INDONESIAN DIGITAL DIPLOMACY @KEMLU_RI}

Social media as a means of communication and dissemination of information has been utilized well by ministries of foreign affairs (MOFA) of various countries (Manor \& Pamment, 2019), including the Indonesian MOFA since 2010 (Hadiansyah, Purwandari, Satria, \& Yudhoatmojo, 2018). The Indonesia MOFA launched its official website in 1996, developed in 2008, and entered version 2.0 in 2016 as part of its policy of digital diplomacy (Tucker Yépez, Pusay Villarroel, \& Samaniego Rojas, 2019). The MOFA has 132 representative offices abroad, such as embassies, consulates generals, and consulates, meaning that it has at least 132 official accounts on Twitter to disseminate diplomatic information and have real-time interaction with local people, both in Indonesia and abroad.

The rapid development of social media, particularly Twitter, has encouraged Indonesian MOFA to use its official Twitter account @Kemlu_RI to convey information on the preparation, implementation, and various influential agendas, including the BDF 2019. For this BDF 2019, MOFA created a unique hashtag \#BDF2019. As a social media platform, Twitter users can post various issues, follow other people's tweets, and repost the issues they like (Umakanth \& Santhi, 2020).
Communication among Twitter users takes place through mentioning and answering previous tweets. Twitter's popularity among diplomats has been the focus of this research (Sevin et al., 2018). Twitter uses hashtags as keywords that describe tweets and help search for specific information on Twitter (Small, 2011). Therefore, hashtags have a significant meaning for managing data on Twitter (Ittefaq, 2019).

MOFA has put social media as a strategic means of communication and information dissemination. Minister Retno Marsudi asserted the importance of technology, amazing teamwork, and officials' responsibility for solving diplomatic problems. By adopting digital diplomacy, Indonesia's MOFA should make an institutional response. One of the responses was the establishment of digital infrastructures, such as the Digital Command Center (DCC). The DCC serves as the MOFA's crisis management center. Its main function is to watch, monitor, and analyze the trend of conversations in social media, including Twitter.

With and without using DEA, the search for conversations using the keywords @Kemlu_RI and hashtags \#BDF2019 generated different results. A search using @Kemlu_RI and \#BDF2019 as keywords (24/07/2020) through Google Search discovered 416 results. The Google search results are still generic and have not been categorized into specific groups of issues, such as those on Twitter that have tweets, retweets, and replies. Therefore, the results of this Google search tend to complicate the further analysis of the successful dissemination of the @Kemlu_RI information regarding \#BDF2019.

In Figure 1, the monitoring of Twitter's conversations at @Kemlu_RI about \#BDF2019 generated a total of 1,088 conversations from $3^{\text {rd }}$ to $7^{\text {th }}$ December 2019. The entire conversation was grouped into 145 mentions, 406 replies, and 537 retweets. Unlike Facebook and Instagram, Twitter uses terms of mention, reply, and retweet, referring to the interaction rate of the specific hashtag, which becomes a conversation topic at a particular Twitter account (Saravanan et al., 2020). The higher the interaction rate, the higher the topic becomes trending on Twitter (Gruzd \& Wellman, 2014). A specific hashtag represents the topic of conversation. 


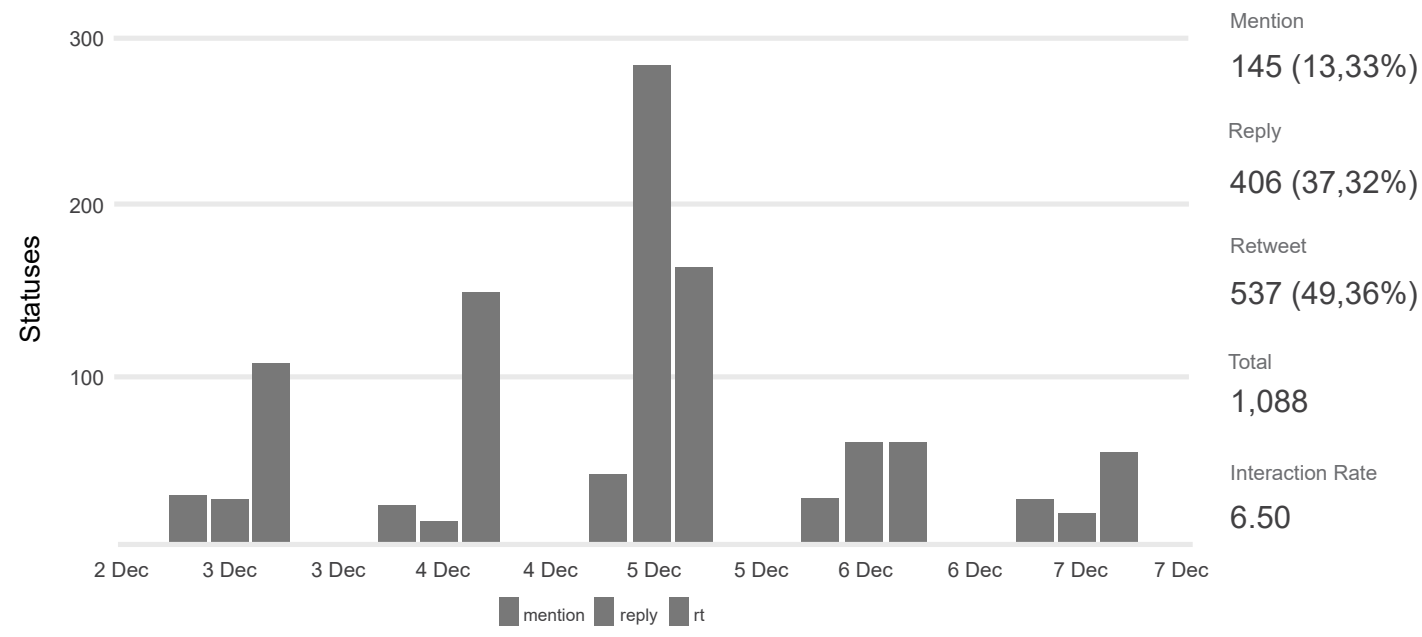

Figure 1. The Trend of Conversations at @Kemlu_RI, 3rd-7th December 2019 (DEA, 2019)

On the other hand, the finding of Figure 1 (DEA, 2019) suggests that the use of DEA has made a significant difference from the use of Google Search for mining \#BDF2019 data at @Kemlu_RI. The use of DEA generated Twitter conversation findings at the @Kemlu_RI account with the \#BDF2019 hashtag more accurate in conversation counts and could be grouped into mentions, replies, and retweets.

Figure 1 (DEA, 2019) also demonstrates that the trend of conversations or tweeting on \#BDF2019 increases among Twitter users from 3rd to 5th December 2019. Besides, the use of DEA showed an increase in the number of conversations from 3rd December or two days before the implementation of BDF 2019 on 5th December 2019. This finding indicates the significance of determining the right time (Booten, 2016) for the MOFA to convey information about an agenda or issue of diplomacy, including BDF2019, to the public through its Twitter account @Kemlu_RI using a custom hashtag, such as \#BDF2019.

Further analysis of Figure 1 closely relates to the tweets grouping into mention, reply, and retweet. The more detailed results of the DEA analysis are significant because they can uncover who is actively doing the three activities of the conversations (Felt, 2016). Discussion about the number of conversations could show strategic results regarding the participation of the Indonesian MOFA -including its internal organizations-m and the public. The number 145 mentions of the 1,088 total conversations in @Kemlu_RI can be considered relatively few and indicate two possibilities. Firstly, the number shows that the possibility of participation of Indonesian representative offices abroad is less than the community. With a total of 132 Indonesian representative offices abroad, the number of mentions \#BDF2019 at the @Kemlu_RI account should be more than 145 mentions, as in Figure 1.

Secondly, the participation of the Indonesian representative office abroad is more likely than the community. If this possibility is actual, the level of participation or involvement of people--both in Indonesia and abroad-mis still low, as Figure 1 illustrates. This possibility raises questions, as well. With the amount of 162,000 followers during the implementation of BDF 2019, the success rate of information dissemination of BDF 2019 can also be questioned. In a more specific context, the followers of 132 overseas Indonesian representative accounts should also provide a higher number and trend of conversations than those in Figure 1.

Figure 1 has also demonstrated the level of community participation in conversations about \#BDF2019 tweeted by the @Kemlu_RI account. The level of community 
participation in the form of mentions, retweets, and replies can be a measure of successful dissemination (Booten, 2016) of @Kemlu_RI information through \#BDF2019. In addition, the conversation data collected by DEA also demonstrates internal support and commitments (Al-Muftah, Weerakkody, Rana, Sivarajah, \& Irani, 2018) within the Indonesian MOFA through 132 Twitter accounts of Indonesia representatives abroad, including embassies, consulates generals, and consulates.

Furthermore, the number of mentions in Figure 1 should still be increased by the Honorary Consulate offices in some countries and BDF 2019 participants. Suppose the use of DEA resulted in low support of internal accounts in the MOFA and Indonesian representatives abroad; in that case, the MOFA must review the digital diplomacy policy so far, especially regarding the promotion strategy of the Indonesian diplomacy agenda. This internal effort is expected to increase the use of Twitter, typically more serious among Indonesian diplomats, both on duty in Jakarta and other countries.

Another factor that can increase the potential mentions of \#BDF2019 is 250 delegates from 90 countries and seven international organizations coming to BDF 2019. In addition to mentioning \#BDF2019, the 250 delegates were beneficial in increasing the number of tweets, retweets, and reply hashtags \#BDF2019. It seems that MOFA did not convey information about the significance of the hashtag \#BDF2019 in various meetings at BDF 2019, either directly or indirectly. Meanwhile, the Indonesian MOFA should also internally ask the Indonesian embassies in 90 home countries of the 250 delegates who came to BDF 2019 to make special promotions on the delegation in each of the accounts of the Indonesian representatives abroad.

Some of the factors above show many opportunities that Indonesian MOFA can still utilize to increase Twitter usage as a tool of diplomacy to disseminate information about BDF 2019. The use of the DEA extensive data system revealed more significant benefits of Twitter's use in Indonesian diplomacy. Through DEA, Indonesian MOFA could analyze the participation rate of the general public, Indonesian representative office abroad, and delegation. This level of participation and commitment will enable MOFA to determine the strategy of dissemination of information more accurately.

\section{TWEETING \#BDF2019}

As a forum of annual multilateral diplomacy, the goal of BDF 2019 encourages the development of political freedom (Brigg, Wilson, de Jalong, \& Sugiono, 2016) in the Asia Pacific region on an inclusive and open basis (Lie \& Siagian, 2018) by following the commitment of digital diplomacy of the Indonesian MOFA. The BDF 2019 was originally a forum for Asia-Pacific countries. However, in its development, this forum opened participation to more countries and international organizations from various regions, including European and North American countries (Grzywacz, 2019). The increasing number of participants significantly proved the critical role of Indonesia in leading BDF and acknowledgment from the international community of Indonesia's serious efforts in promoting Indonesia's Pancasila democracy (Duncombe, 2017) and building democracy in the region (Karim, 2016).

As the BDF organizer, Indonesia takes on various roles and collaborative initiatives. One of them is the dissemination of information on BDF 2019. Indonesia used multiple social media platforms, particularly Twitter, through the @Kemlu_RI account with a particular hashtag \#BDF2019. Through the Twitter account, Indonesian MOFA promotes and encourages regional and international cooperation in peace and democracy through dialogue in real-time with the community, both in Indonesia and abroad.

In addition to Twitter, the Indonesian MOFA also uses an Instagram account of @Kemlu_RI and a Facebook account of Kemlu.RI to implement the digital diplomacy policy. With 246,000 followers, a search of \#BDF2019 through Instagram search generated 2,688 posts. Meanwhile, its Facebook account had 85,422 followers. The use of Google Search (29-07-2019) to search for keywords Kemlu. RI and \#BDF 2019 resulted in 478 findings. However, without any particular analytics application, the search results on Instagram and 
Facebook were difficult to analyze further. The difficulty of further analysis of the hashtag search results \#BDF2019 on Instagram and Facebook accounts resembles the difficulty in analyzing Twitter conversations without using DEA.

The use of DEA resulted in the visualization of various hashtags of the diplomacy agenda of the MOFA from $3^{\text {rd }}$ to $7^{\text {th }}$ December 2019. Figure 2 (DEA, 2019) depicts the top hashtags from @Kemlu_RI for five days, with a total of over 1,000 conversations. Top hashtags included \#BDF2019 with the most tweets (461 tweets), \#IndonesianWay (237 tweets), \#IniDiplomasi (44 tweets), \#Indonesia (23 tweets), and \#BDSC2019 (13 tweets). Twitter interestingly provides many ways to influence others, such as direct interaction, using \#hashtags to connect communities that share similar interests, and "retweet" messages to other followers (Gruzd \& Wellman, 2014). The visualization of the top hashtags is fascinating concerning the policy, especially in using hashtags as a promotional strategy for Indonesia's diplomacy agenda.

First, the top hashtags in Figure 2 (DEA, 2019) indicate interesting results related to the emergence of hashtags \#IniDiplomasi and \#IndonesianWay. Hashtag \#IniDiplomasi has 44 tweets during the data retrieval period on 3rd-7th December 2019. The number of \#IniDiplomasi raises important questions regarding the commitment of the @Kemlu_RI account and Twitter accounts of 132 Indonesian representatives abroad in writing the hashtag when they post information on their accounts. The purpose of using a hashtag is to expand the influence of the information conveyed and the breadth of their tweets among Twitter users (Collins et al., 2019). This commitment is essential as a form of institutional support to the hashtag \#IniDiplomasi as the official hashtag for the Indonesian MOFA account and Indonesian representative office abroad. The commitment of writing the hashtag \#IniDiplomasi should result in at least 132 tweets instead of just 44 tweets during the data retrieval period from 3rd to $7^{\text {th }}$ December 2019. This amount is equal to the number of Indonesian representative offices abroad, although performed at the same time as the hashtag \#BDF2019 as the primary hashtag.

Secondly, the hashtag \#IndonesianWay also displays that @Kemlu_RI has another strategic diplomacy agenda at the same time as the BDF 2019. With 237 tweets, the \#IndonesianWay turned out to gain more attention than \#IniDiplomasi, whereas \#IniDiplomasi was the official hashtag of the MOFA. With these three crucial hashtags (\#BDF2019, \#IndonesianWay, and \#IniDiplomasi), MOFA must consider a better utilization strategy for Twitter hashtags in the future. Otherwise, the digital diplomacy of MOFA via Twitter would become unfocused and not achieve the objectives of digital diplomacy. Therefore, Twitter utilization, including hashtags, as part of digital diplomacy requires more serious attention.

Thirdly, in the Bali Democracy Student Conference (BDFC) youth panel, the Indonesian MOFA made an exceptional hashtag \#BDSC2019. The hashtag, unfortunately, only generated 13 tweets. This tweet count

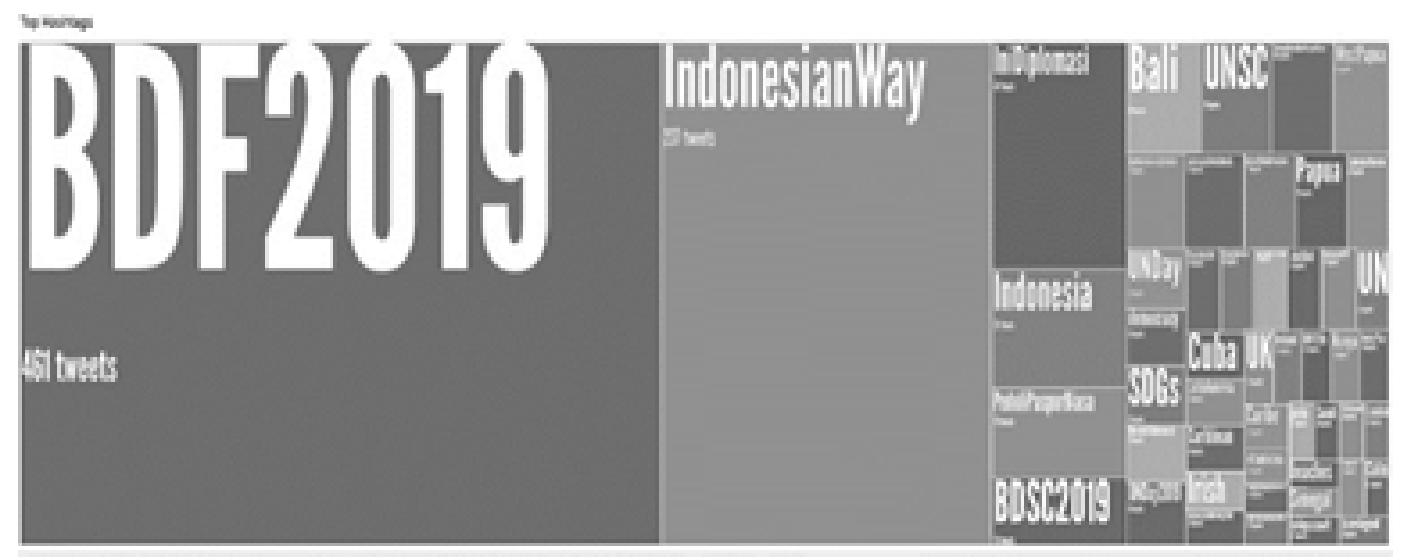

Figure 2. Visualization of Top Hashtags, $3^{\text {rd }}-7^{\text {th }}$ December 2019 (DEA, 2019) 
did not represent the 113 participants of BDSC 2019, which came from 50 countries. During BDF 2019, MOFA also organized Non-Government Organizations (NGOs), media, youth, and entrepreneurs. While the main forum of BDF 2019 presented 250 delegates from 90 countries and seven international organizations. The existence of five panels should be able to increase the number of community participation in the form of Twitter conversation numbers about BDF 2019 through hashtags \#BDF2019 and BDSC 2019 through \# BDSC2019.

The fact that \#BDSC2019 only generates 13 tweets, as in Figure 2, raises questions about the cause. There were several possible explanations for the low number of tweets \#BDSC2019. Firstly, the lack of attention of the MOFA in the socialization of the \#BDSC2019 hashtag among the participants in BDSC 2019. Most likely, the Indonesian MOFA focused more attention on the main forum of the BDF 2019, which was the meeting of delegates from 90 countries and seven international organizations. Secondly, the lack of internal coordination among the organizers of BDF 2019 and BDSC 2019 in communicating information to BDSC 2019 participants on the strategic meaning of the hashtag \#BDSC2019 in Indonesia's digital diplomacy. The third possibility, the most fundamental of which was the lack of awareness of Indonesia and participants about the significance of the hashtag \#BDSC2019 for digital diplomacy. As a result, the use of the unique hashtag of the BDSC2019 did not lead to maximum results.

In a more general context, the Indonesian MOFA seems to have no specific policy on the urgency of the use of hashtags in its digital diplomacy on Twitter. Without the DEA, the data would not appear, thus not producing a more in-depth analysis. It seems that policy on digital diplomacy through Twitter is still general in its purposes, namely as a tool to promote the agenda of diplomacy and interaction with the community. Therefore, this paper resulted in a more profound analysis of Twitter conversation data and other critical issues beneficial for Indonesia's digital diplomacy, such as Indonesia's role in increasing ASEAN's response to COVID-19 in multilateral diplomacy to secure access to COVID-19 vaccines to developing countries.

\section{TRENDING TOPICS AND CHALLENGES}

The Indonesian MOFA and overseas representative offices use various social media in their public diplomacy. Rather than using Google Search, the use of DEA in mining conversation data at the @Kemlu_RI account generates the top influencers of \#BDF2019, as in Figure 3. With 182,000 followers, Figure 3 shows that @Kemlu_RI is capable of resulting in 470 engagements on the topic of \#BDF2019. The engagement included reply, mention, and retweet activities on Twitter, enabling to increase public interaction in an interconnected network (Uysal \& Schroeder, 2019). Both personal (@antilalat, @kangdede78, and @LiwangJemmy) and institutional accounts (@indonesiaunny, which belongs to the Indonesian Permanent Representative to the United Nations in New York) involved in the engagement of \#BDF2019 for less than 100.

The top influencer data of Figure 3 (DEA, 2019) reveals a lack of activity in collaboration of tweets and retweets between the @Kemlu_RI account and other internal accounts within the MOFA, both in Jakarta and overseas representatives (e.g., @indonesiaunny). The low number of engagements from Twitter accounts within Indonesian MOFA (@Kemlu_RI account and 132 Twitter accounts from overseas Indonesian representatives) significantly demonstrated a lack of internal commitment to digital diplomacy policy. @Indonesiaunny (54 engagement) depicted that its institutional support and participation in the dissemination \#BDF2019 was higher than that of other Indonesian representative Twitter accounts abroad.

Figure 3 also reveals that the commitment of 132 Indonesian representative offices abroad through their Twitter account should have no problems-at least, technical issues-supporting the implementation of the annual forum BDF 2019. In this situation, Indonesian MOFA, through its Directorate of Public Information, must rearrange Twitter's utilization strategy for its representative offices abroad. Another suggestion on the use of Twitter for public diplomacy is the necessity of training programs for diplomats on the significance and use of social media, particularly Twitter, for Indonesian 
diplomacy. In addition, this issue shows that the MOFA diplomats, as significant stakeholders in digital diplomacy, need to understand the vital role of the tweets and the use of the \#BDF2019 hashtag.

Furthermore, Figure 3 demonstrates that conversations regarding \#BDF2019 indicate that the reach of the @Kemlu_RI account to the community seems to be limited. Only three personal accounts had more than 30 engagements with @Kemlu_RI via \#BDF2019: @antilalat, @kangdede78, and @Liwangjemmy. The limited number of personal accounts in the conversation trend concerning \#BDF2019 explains the lack of community participation in discussing BDF 2019. Nevertheless, the findings also imply that the Indonesian MOFA still has an excellent opportunity to improve community engagement in conversations on Twitter on various diplomacy agendas, including BDF 2019 through \#BDF2091. In the context of engagement, the use of DEA could support the Indonesian MOFA to have a better assessment of the success rate of information dissemination of BDF 2019 through \#BDF2019.

Figure 4 (DEA, 2019) exhibits the Social Network Analysis (SNA) visualization of the top influencers using \#BDF2019. The SNA visualization clearly shows networks of Twitter actors who tweet information to their followers (Sevin et al., 2018). The caase of BDF 2019 depicted the SNA of five groups of social networks in \#BDF2019 conversations: @Kemlu_RI,
@Indonesianunny, @antilalat, @kangdede78, and @Liwangjemmy. The visualization also illustrated that the five groups were not in the pro and counter positions against the BDF 2019. Figure 4 (DEA, 2019) presents that the three top influencers (@antilalat, @kangdede78, and @Liwangjemmy) and their respective groups support the @Kemlu_RI in the implementation of the Indonesian diplomacy agenda at BDF 2019. With this positive outcome, Figure 4 displays that the use of the DEA can help the MOFA identifies Twitter's top influencers to support the dissemination of the diplomacy agenda through a particular hashtag, including the implementation of BDF 2019. This identification is highly beneficial for devising strategies for the dissemination of digital diplomacy information.

In addition to the ability to identify top influencers, Figure 4 also visually shows the possibility of the Indonesian MOFA for establishing a more strategic cooperative relationship with top influencers. In the context of Twitter, top influencers play an important role in inviting their followers into conversations about specific issues through particular hashtags (Dodd \& Collins, 2017), such as \#BDF2019. The engagement of top influencers and their followers can be seen in the SNA visualization of those groups in Figure 4. Through such cooperation, MOFA has strategic stakeholders among Twitter users. In addition to top influencers, MOFA and its 132 overseas representative offices are also

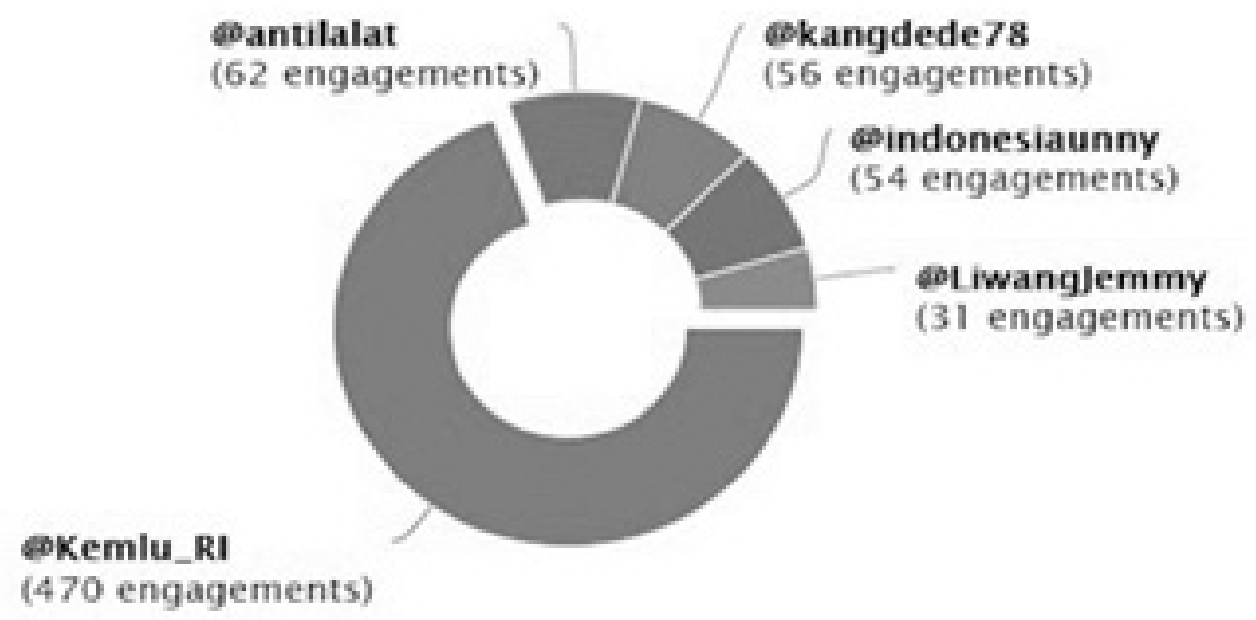

Figure 3. Top Influencers of \#BDF2019 (DEA, 2019) 
the main stakeholders (Albishri, Tarasevich, Proverbs, Kiousis, \& Alahmari, 2019). Top influencers can actively and positively support the MOFA strategy in disseminating information more broadly to the community, both in Indonesia and abroad.

Table 1 (DEA, 2019) demonstrates the most engaged users who talk about the issue of \#BDF2019 during the data retrieval period. The table interestingly reveals the engagement of the embassy's account, such as the @KBRILondon account (17 RT and Reply) of the Indonesian Embassy in London, UK. Unfortunately, their engagements were lower than one of the personal accounts, such as@LiwangJemmy (31 RT and Reply). The table indirectly indicates a lack of internal support for the promotion of BDF 2019 among Indonesian diplomats through its hashtag \#BDF2019.

The Indonesian MOFA needs to pay more serious attention to this problem because it is closely related to internal support in the organization of the ministry. In this case, MOFA should appreciate two Twitter accounts of Indonesian representative offices abroad --@Indonesiaunny (54 RT and Reply) of the Indonesian Permanent Representatives to the United Nations in New York and @KBRILondon accounts (17 RT and Reply) --that had resulted in more engagement numbers. The two overseas Indonesian representatives' Twitter accounts have demonstrated reliable support in the form of several retweets and replies to the \#BDF2019 hashtag.
On the other hand, the use of the DEA allowed Indonesian MOFA to identify Twitter accounts from Indonesian representatives abroad who did not appear in Table 1 and could be considered fewer active accounts. This identification effort was significant to know the issues these representatives faced in supporting digital diplomacy policy through Twitter. This issue became urgent to get the MOFA's attention because 132 Indonesia representative accounts abroad were a significant part of the stakeholders of digital diplomacy. In addition, the Indonesian MOFA could also provide a better understanding of the linkages between the engagement rate of accounts of embassies and consulates of Indonesia abroad and the number of conversations about \#BDF2019 for several days before and after the BDF 2019.

In early 2017, the Indonesian MOFA announced the policy of digital diplomacy as a form of a concrete response to the increase in the use of social media in diplomacy. Since then, MOFA has been highly active in using various social media platforms as part of its public diplomacy strategy in the digital age, including Twitter. The MOFA also initiated several national and international forums on digital diplomacy involving the general public, young millennials, influencers, digital business groups, and diplomats. These initiatives demonstrate the strong commitment of MOFA in carrying out digital diplomacy.

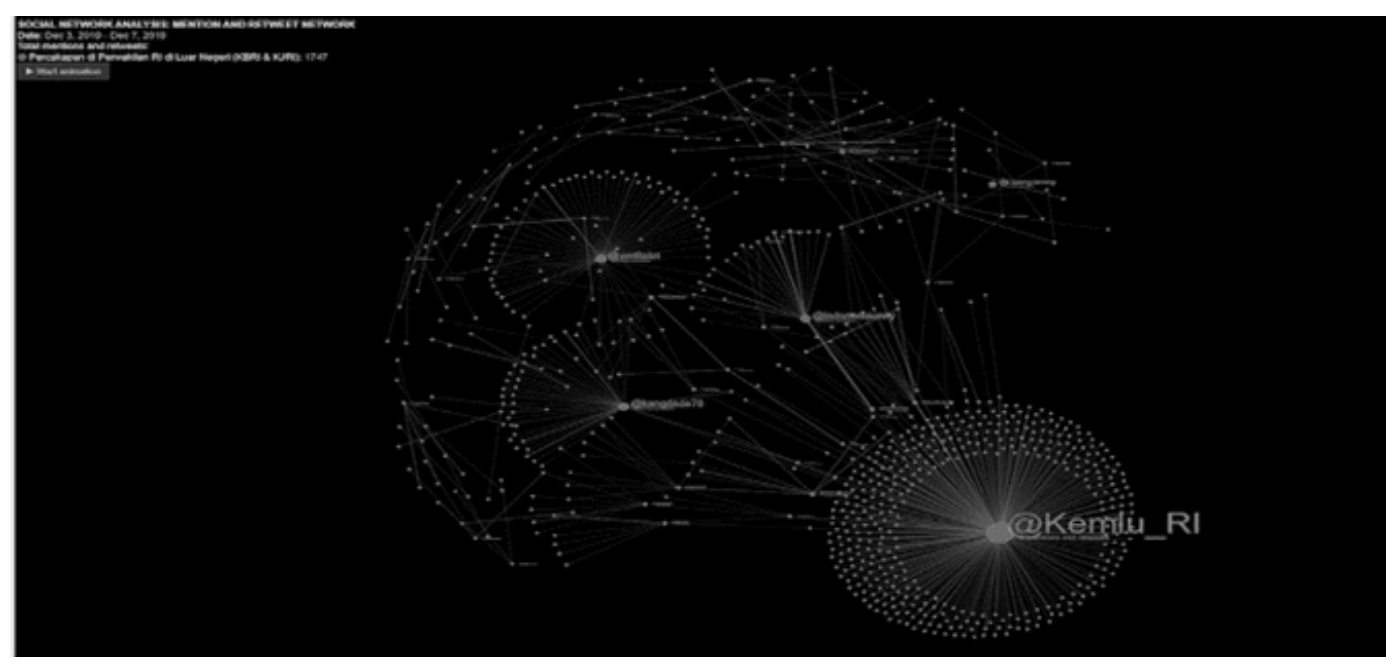

Figure 4. Social Network Analysis (DEA, 2019) 
Table 1. MOST ENGAGED USERS

\begin{tabular}{clc}
\hline No & Most Engaged Users & \#RT+Reply \\
\hline 1 & @Kemlu_RI & 470 \\
\hline 2 & @antilalat & 62 \\
\hline 3 & @kangdede78 & 56 \\
\hline 4 & @indonesiaunnyt & 54 \\
\hline 5 & @LiwangJemmy & 31 \\
\hline 6 & @TImMarbun & 17 \\
\hline 7 & @KBRILondon & 17 \\
\hline 8 & @oak_math_lee_91 & 12 \\
\hline 9 & @WFD_Indonesia & 9 \\
\hline 10 & @EmbaCuIndonesia & 9 \\
\hline 11 & @UKinINdonesia & 8 \\
\hline 12 & @EllaZefa & 10 \\
\hline
\end{tabular}

Note. Data is adapted from Drone Emprit Academic, Universitas Islam Indonesia

(DEA, 2019)

In early 2017, the Indonesian MOFA announced the policy of digital diplomacy as a form of a concrete response to the increase in the use of social media in diplomacy. Since then, MOFA has been highly active in using various social media platforms as part of its public diplomacy strategy in the digital age, including Twitter. The MOFA also initiated several national and international forums on digital diplomacy involving the general public, young millennials, influencers, digital business groups, and diplomats. These initiatives demonstrate the strong commitment of MOFA in carrying out digital diplomacy.

Using DEA, the analysis of the Twitter data at the @Kemlu_RI account with the specific hashtag \#BDF2019 mostly showed the extent to which Twitter affected the annual activity of BDF 2019. On the one hand, the data uncovered that the intensity of conversational interactions regarding the \#BDF2019 had successfully become a top hashtag during the implementation of BDF 2019. Even the hashtag was able to challenge the official hashtags of the Kemlu, i.e., \#IniDiplomasi and \#SahabatKemlu. Both hashtags were always written on Twitter news at @Kemlu_RI and 132 accounts of Indonesian representatives abroad.

In addition to the news written using the hashtag, MOFA must review the news writing or information at the @Kemlu_RI account and 132 accounts of Indonesian representatives abroad to the Indonesian language and the national language and English as a diplomatic language (Šimunjak \& Caliandro, 2019). Since each account of the Indonesian representative abroad has its followers, the language use of this information writing strategy is beneficial in attracting more local people's attention. The use of the national language at least encourages people to know Indonesia's diplomacy agenda.

On the other hand, Twitter diplomacy needs to consider the patterns of mentions (tweets and retweets) among the top influencers. Although top influencers are still included in the internal MOFA, the Twitter activity of the Indonesian representatives abroad needs to be more equitable. It is mainly applied for Indonesian representative offices, which become the country of origin of official delegates and participants-whether 
students, media, or civil society-of the BDF 2019. In this context, MOFA should consider the possibility of expanding top influencers among Indonesians who become diaspora and foreigners who become Indonesian companions (Friends of Indonesia) in various countries.

In the end, Twitter's diplomacy through the @Kemlu_RI account needs to be adapted to the needs of the Indonesian Government in diplomacy on specific issues over a period of time. The priority of diplomacy in the form of particular hashtags wsuch as \#BDF2019--must be developed according to the needs of Indonesian diplomacy in certain countries. For example, Indonesia's trade promotion in Egypt should be supported by forming a hashtag in Twitter's account of Indonesia's representative in the country. The use of DEA in analyzing makes the Indonesian MOFA have more possibilities of demonstrating the symbolization of the 'country's presence' (or 'negara hadir' in the Indonesian language) beyond its initial purpose of mere dissemination of information about Indonesian diplomacy to the broader community, both nationally and internationally.

\section{CONCLUSION}

Following the purpose of this study, this paper shows that the Twitter account @Kemlu_RI with its special hashtag \#BDF2019 resulted in more strategic findings on the top hashtags, top influencers, social network analyses, and most engaged users for Indonesian digital diplomacy. This study evaluated the use of Twitter in promoting BDF 2019 through its mentions, retweets, and replies. It produced more detailed findings, consisting of the top hashtags, top influencers, social network analyses, and most engaged users rather than just general dissemination of information of the BDF 2019. By analyzing the trend of conversation on Twitter, especially at Kemlu's official account @Kemlu_RI, with its special hashtag \#BDF2019, those findings importantly displayed the levels of participation, commitment, and support of stakeholders and the public. Therefore, the use of Twitter for the Indonesian MOFA's digital diplomacy policy is vital for developing strategic aims of Indonesian diplomacy in various countries in the future.

\section{ACKNOWLEDGEMENT}

The author would like to acknowledge Drone Emprit Academic at UII (dea.uii.ac.id) for providing the Twitter data as the primary source of analysis of this study.

\section{REFERENCE}

Al-Muftah, H., Weerakkody, V., Rana, N. P., Sivarajah, U., \& Irani, Z. (2018). Factors influencing e-diplomacy implementation: Exploring causal relationships using interpretive structural modeling. Government Information Quarterly, 35(3), 502-514. https://doi.org/https://doi.org/10.1016/j.giq.2018. 03.002

Albishri, O., Tarasevich, S., Proverbs, P., Kiousis, S. K., \& Alahmari, A. (2019). Mediated public diplomacy in the digital age: Exploring the Saudi and the U.S. governments' agenda-building during Trump's visit to the Middle East. Public Relations Review, 45(4), 101820. https://doi.org/ https://doi.org/10.1016/j.pubrev.2019.101820

Anam, K., M Kolopaking, L., \& A Kinseng, R. (2020). The Effectiveness of Social Media Usage within Social Movement to Reject the Reclamation of the Jakarta Bay, Indonesia. Sodality: Jurnal Sosiologi Pedesaan, 8(1), 64-81. https://doi .org/10.22500/8202028955

Booten, K. (2016). Hashtag Drift. 2401-2405. Retrieved January 13, 2021, from doi: https://doi.org/10.1145/2858036. 2858398

Brigg, M., Wilson, L., de Jalong, F., \& Sugiono, M. (2016). Diversity, democratisation and Indonesian leadership. Australian Journal of International Affairs, 70(4), 407-421. https://doi.org/10.1080/10357718.2016.1153599

Chhabra, R. (2020). Twitter Diplomacy: A Brief Analysis. orfonline.org. Retrieved December 20, 2020, from Orfonline: https://www.orfonline.org/wp-content/uploads /2020/01/ORF_IssueBrief_335_TwitterDiplomacy.pdf

Collins, S. D., DeWitt, J. R., \& LeFebvre, R. K. (2019). Hashtag diplomacy: twitter as a tool for engaging in public diplomacy and promoting US foreign policy. Place Branding and Public Diplomacy, 15(2), 78-96. https://doi.org/10. 1057/s41254-019-00119-5

Dodd, M. D., \& Collins, S. J. (2017). Public relations message strategies and public diplomacy 2.0: An empirical analysis using Central-Eastern European and Western Embassy Twitter accounts. Public Relations Review, 43(2), 417-425. https://doi.org/10.1016/j.pubrev.2017.02.004

DEA (Drone Emprit Academic). (2019). My project: Diplomacy of Indonesia's MOFA on BDF 2019. https://dea.uii.ac.id

Duncombe, C. (2017). Twitter and transformative diplomacy: social media and Iran-US relations. International Affairs, 93(3), 545-562. https://doi.org/10.1093/ia/iix048

Fahmi, I. (2017). Drone Emprit: Konsep dan Teknologi. Retrieved October 28, 2019, from IT Camp on Big data and Data Mining, Jakarta.

Felt, M. (2016). Social media and the social sciences: How researchers employ Big Data analytics. Big Data and Society, 3(1), 1-15. https://doi.org/10.1177/2053951716645828 Gruzd, A., \& Wellman, B. (2014). Networked Influence in Social 
Media: Introduction to the Special Issue. American Behavioral Scientist, 58(10), 1251-1259. https://doi.org/10. $1177 / 0002764214527087$

Grzywacz, A. (2019). Indonesia's (inter)national role as a Muslim democracy model: effectiveness and conflict between the conception and prescription roles. Pacific Review. https://doi .org/10.1080/09512748.2019.1585387

Hadiansyah, H., Purwandari, B., Satria, R., \& Yudhoatmojo, S. B. (2018). Social media strategies for public diplomacy: A case study in the Ministry of Foreign Affairs of the Republic of Indonesia. Proceedings of the 2nd International Conference on Informatics and Computing, ICIC 2017. https://doi.org /10.1109/IAC.2017.8280636

Hanson, F. (2012, October 25). Baked in and wired: eDiplomacy@State. Foreign Policy Paper Series no 30 (pp. 1-41), Brookings Institution; Washington, DC.

Ittefaq, M. (2019). Digital diplomacy via social networks: a cross-national analysis of governmental usage of Facebook and Twitter for digital engagement. Journal of Contemporary Eastern Asia, 18(1), 49-69. https://doi.org /10.17477/jcea.2019.18.1.049

Karim, M. F. (2016). Role conflict and the limits of state identity: the case of Indonesia in democracy promotion. Pacific Review, 30(3), 1-20. https://doi.org/10.1080/09512748. 2016.1249908

Laagu, M. A., \& Setyo Arifin, A. (2020). Analysis of the Issue of Increasing National Health Insurance (BPJS Kesehatan) Rates through Community Perspectives on Social Media: A Case Study of Drone Emprit. Proceeding - ICOSTA 2020: 2020 International Conference on Smart Technology and Applications: Empowering Industrial loT by Implementing Green Technology for Sustainable Development. https://doi. org/10.1109/ICOSTA48221.2020.1570615599

Lewis, D. (2014). Digital diplomacy. Retrieved January 10, 2021, from: Gateway House http://www.gatewayhouse.in/digital -diplomacy-2/

Lie, W., \& Siagian, M. (2018). Indonesian Interests in Bali Democracy Forum. Advances in Social Science, Education and Humanities Research, Volume 241 5th International Conference on Social and Political Sciences (IcoSaPS 2018), 49-54. https://doi.org/10.2991/icosaps-18.2018.15

Manor, I. (2015). The social network of G20 leaders. Retrieved January 15, 2021, from G20 Live. http://g20live.com/thesocial-network-of-g20-leaders.php

Manor, I., \& Segev, C. (2015). America's selfie: How the US portrays itself on its social media accounts. In C. Bjola \& M. Holmes (Eds.), Digital diplomacy: Theory and practice (pp. 89-108). Routledge; New York, NY.

Manor, I., \& Segev, E. (2020). Social Media Mobility: Leveraging Twitter Networks in Online Diplomacy. Global Policy, 11(2), 232-244. https://doi.org/10.1111/1758-5899.12799

Manor, I., \& Pamment, J. (2019). Towards prestige mobility? Diplomatic prestige and digital diplomacy. Cambridge Review of International Affairs. https://doi.org/10.1080 /09557571.2019.1577801

Mattoš, B. (2015). Effects of information and communication technology on diplomacy and foreign policy administration. International Journal of Social Ecology and Sustainable Development, 6(1), 17-27. https://doi.org/10.4018/ijsesd.

\section{2}

Potter, E. H. (2002). Cyber-diplomacy: Managing foreign policy in the twenty-first century, McGill-Queen's Press; Ontario.

Rold, Ana C. (2018). Reshaping Diplomacy for the Digital World. Retrieved January 16, 2021, from: Diplomatic Courier. https://www.diplomaticourier.com/2018/02/27/reshaping -diplomacy-digital-world/

Saravanan, C., Masthan, M. A., Kethri K, S., Harsha, C., \& Reddy, M. A. (2020). Analysis of trending hashtags on Twitter. Journal of Critical Reviews, 7(07), 1863-1867.

Sevin, E., Manor, I., Ittefaq, M., Setiadi, T., Manor, I., Segev, E., \& CHHABRA, R. (2018). From embassy ties to Twitter links: Comparing offline and online diplomatic networks. Policy \& Internet, 9999, 1-20. https://doi.org/10.1002/poi3.199 \#

Šimunjak, M., \& Caliandro, A. (2019). Twiplomacy in the age of Donald Trump: Is the diplomatic code changing? Information Society, 35(1), 13-25. https://doi.org/10.1080 /01972243.2018.1542646

Small, T. A. (2011). What the Hashtag? Information, Communication \& Society, 14(6), 872-895. https://doi.org/ 10.1080/1369118x.2011.554572

Sobel, M., Riffe, D., \& Hester, J. B. (2016). Twitter Diplomacy? A Content Analysis of Eight US Embassies' Twitter Feeds. The Journal of Social Media in Society, 5(2), 75-107. Retrieved from https://www.thejsms.org/index.php/TSMRI/article/view $/ 168 / 79$

Strauß, N., Kruikemeier, S., van der Meulen, H., \& van Noort, G. (2015). Digital diplomacy in GCC countries: Strategic communication of Western embassies on Twitter. Government Information Quarterly, 32(4), 369-379. https:// doi.org/10.1016/j.giq.2015.08.001

Suharso, P. (2019). Pemanfaatan Drone Emprit dalam Melihat Trend Perkembangan Bacaan Digital melalui Akun Twitter. Anuva, 3(4), 333-346. Retrieved from http://ejournal.undip .ac.id/index. php/anuva\%0APemanfaatan

Tucker Yépez, J. J., Pusay Villarroel, B. A., \& Samaniego Rojas, P. A. (2019). Analysis of digital diplomacy and E-society in the context of internet governance. International Journal of Engineering and Advanced Technology, 8(3), 134-139.

Umakanth, N., \& Santhi, S. (2020). Classification and ranking of trending topics in Twitter using tweets text. Journal of Critical Reviews, 7(4), 895-899. https://doi.org/10.31838/jcr .07 .04 .171

Uysal, N., \& Schroeder, J. (2019). Turkey's Twitter public diplomacy: Towards a "new" cult of personality. Public Relations Review, 45(5). https://doi.org/10.1016/j.pubrev. 2019.101837

Verrekia, B. (2017). Digital Diplomacy and Its Effect on International Relations. Independent Study Project.

Xiong, Y., Cho, M., \& Boatwright, B. (2019). Hashtag activism and message frames among social movement organizations: Semantic network analysis and thematic analysis of Twitter during the\# MeToo .... Public Relations Review, 45(1), 10-23. Retrieved from https://www.sciencedirect.com/ science/article/pii/S0363811118302303 